\section{Characterization and Preliminary Assessment of a Sorbent Produced by Accelerated Mineral Carbonation}

\author{
O LGA L. SHTEPENKO, *, \\ C O L I N D. H I L L S , \\ NICHOLA J. COLEMAN, ${ }^{\dagger}$ AND \\ A D R I A N B R O U G H ${ }^{\ddagger}$ \\ Centre for Contaminated Land Remediation, \\ University of Greenwich at Medway, \\ Chatham Maritime ME4 4TB, U.K., and \\ Department of Civil Engineering and Materials, \\ University of Leeds, Leeds LS2 9JT, U.K.
}

This study shows that calcium silicate/aluminate-based materials can be carbonated to produce sorbents for metal removal. The material chosen for investigation, cement clinker, was accelerated carbonated, and its structural properties were investigated using X-ray diffraction (XRD), scanning electron microscopy, thermal gravimetric and differential thermal analysis, nuclear magnetic resonance spectroscopy, and nitrogen gas adsorption techniques. The principal carbonation reactions involved the transformation of dicalcium silicate, tricalcium silicate, and tricalcium aluminate into a Ca/Al-modified amorphous silica and calcium carbonate. It was found that carbonated cement had high acid buffering capacity, and maintained its structural integrity within a wide $\mathrm{pH}$ range. The uptake of $\mathrm{Pb}(\mathrm{II}), \mathrm{Cd}-$ (II), $\mathrm{Zn}(\mathrm{II}), \mathrm{Ni}(\mathrm{II}), \mathrm{Cr}(\mathrm{III}), \mathrm{Sr}(\mathrm{II}), \mathrm{Mo}(\mathrm{VI}), \mathrm{Cs}(\mathrm{I}), \mathrm{Co}(\mathrm{II})$, and $\mathrm{Cu}-$ (II) from concentrated $\left(1000 \mathrm{mg} \mathrm{L}^{-1}\right)$ single-metal solutions varied from 35 to $170 \mathrm{mg} \mathrm{g}^{-1}$ of the carbonate cement. The removal of metals was hardly effected by the initial solution $\mathrm{pH}$ due to the buffering capability of the carbonated material. The kinetics of $\mathrm{Pb}, \mathrm{Cd}, \mathrm{Cr}, \mathrm{Sr}, \mathrm{Cs}$, and $\mathrm{Co}$ removal followed a pseudo-second-order kinetic model, whereas the equilibrium batch data for $\mathrm{Cu}$ fitted the pseudofirst-order rate equation. PHREEQC simulation supported by XRD analysis suggested the formation of metal carbonates and silicates, calcium molybdate, and chromium (hydro)oxide. Cesium was likely to be adsorbed by $\mathrm{Ca} / \mathrm{Al}$-modified amorphous silica.

\section{Introduction}

Accelerated carbonation technology has emerged to reduce emissions of carbon dioxide $\left(\mathrm{CO}_{2}\right)$, a "greenhouse" gas, as well as to produce useful materials. The process of accelerated carbonation, where calcium/magnesium-bearing minerals react with $\mathrm{CO}_{2}$ in an accelerated mode (as compared to slow atmospheric carbonation), has the potential to be beneficially exploited for $\mathrm{CO}_{2}$ sequestration $(1-3)$. The technology provides a permanent method for the disposal of $\mathrm{CO}_{2}$ in the form of stable carbonate minerals. It is considered to be sustainable, as the overall process is exothermic and raw

* Corresponding author: phone: +44 (0) 7752269537; e-mail: olga_shtepenko@hotmail.com.

+ University of Greenwich at Medway.

‡ University of Leeds. minerals susceptible to carbonation exist in vast quantities across the globe including peridotites, serpentenites, wollastonite, olivine, garnets, and feldspars $(1-3)$.

Other research into the utilization of $\mathrm{CO}_{2}$ by accelerated carbonation has involved ultrarapid hardening of both anhydrous cements and mature, previously hydrated, cement pastes $(4-10)$. There is also a growing interest in using accelerated carbonation for the solidification/stabilization of wastes to improve their physical properties and to immobilize metallic contaminants $(11-16)$.

In the above-mentioned studies, an acceleration of the reaction between $\mathrm{CO}_{2}$ and substrates has been achieved by adjusting physical conditions including temperature, $\mathrm{CO}_{2}$ pressure, and surface area and/or chemical parameters including the use of activators. The application of accelerated carbonation to date has involved the reaction of materials with $\mathrm{CO}_{2}$ at elevated or ambient pressures and temperatures in the presence of moisture (aqueous carbonation), with $\mathrm{CO}_{2}$ in a supercritical state (supercritical carbonation), and with $\mathrm{CO}_{2}$ at high temperatures (solid-gas carbonation).

Our research examines aqueous accelerated carbonation as a potential process for producing sorbent materials to remove metal contaminants. In this process, $\mathrm{CO}_{2}$ gas can be combined with anhydrous calcium silicate/aluminate minerals found in natural, synthetic forms or as constituents of waste byproducts.

In the present study, Portland cement (PC) clinker, composed of tricalcium silicate $\left(\mathrm{C}_{3} \mathrm{~S}\right)$, dicalcium silicate $\left(\mathrm{C}_{2} \mathrm{~S}\right)$, tricalcium aluminate $\left(\mathrm{C}_{3} \mathrm{~A}\right)$, and tetracalcium aluminoferrate $\left(\mathrm{C}_{4} \mathrm{AF}\right)$, has been selected as a parent material to be carbonated. PC was used as it contains the group of minerals often found in a range of large-volume inorganic industrial byproducts, including slags, ashs, and dusts from material and mineral processing (17-19). However, these wastes are complex heterogeneous mixtures and can be problematic to quantify chemically, so PC was chosen as it represents a well-characterized material with an appropriate mineralogy for this preliminary investigation.

Research pertaining to the accelerated carbonation of anhydrous calcium silicate/aluminate minerals has been mainly focused on reaction kinetics and the mechanical properties of carbonated products, but little has been done on the structural characterization $(1-7,20)$. Several authors (4-6) carbonated $\mathrm{C}_{3} \mathrm{~S}, \beta-\mathrm{C}_{2} \mathrm{~S}, \gamma-\mathrm{C}_{2} \mathrm{~S}$, and $\mathrm{CS}$ (wollastonite) at low water/solid (w/s) ratios, and examined the reaction products using X-ray diffraction (XRD), thermogravimetric and differential thermal analysis (TG-DTA), and gas-phase mass spectroscopy. They observed that the $\mathrm{CaO} / \mathrm{SiO}_{2}$ ratios progressively decreased with increasing carbonation time, resulting in the formation of calcium carbonate and lowlime silica gel. Goto (6), however, questioned the formation of a silica-gel-like reaction product and suggested it was an amorphous calcium silicate hydrocarbonate. As to the accelerated carbonation of $\mathrm{C}_{3} \mathrm{~A}$ and $\mathrm{C}_{4} \mathrm{AF}$, they were believed to be lowly reactive to $\mathrm{CO}_{2}$ gas $(7,20,21)$.

The aim of the present work was to undertake a detailed characterization of the carbonated cement, and evaluate its metal removal efficiencies in a batch sorption study. The material was analyzed by XRD, scanning electron microscopy (SEM), nuclear magnetic resonance (NMR) spectroscopy, TGDTA, and nitrogen gas adsorption techniques, and the principal carbonation products were identified. The acid neutralization test, outlined by Isenburg and Moore (22) and modified by Johnson (23) for carbonate-rich materials, was employed to determine the acid buffering capacity of the carbonated cement, whereas its structural stability was 


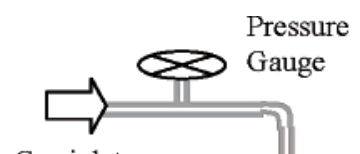

Gas inlet

( $\mathrm{PCO}-2 \mathrm{Bar})$

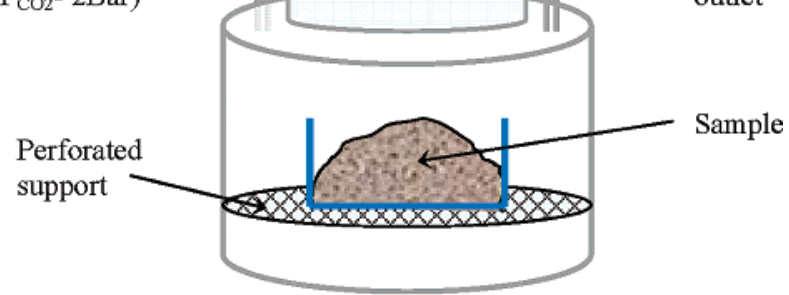

Reaction chamber (Volume $3 \mathrm{~L}$ )

FIGURE 1. Schematic diagram of the carbonation chamber.

TABLE 1. Chemical Composition of Portland Cement

$\begin{array}{crcclc}\text { constituent } & \begin{array}{c}\text { concn } \\ \text { (wt \%) }\end{array} & \text { constituent } & \begin{array}{l}\text { concn } \\ \text { (wt \%) }\end{array} & \text { constituent } & \begin{array}{c}\text { concn } \\ \text { (wt \%) }\end{array} \\ \mathrm{SiO}_{2} & 20.5 & \mathrm{SO}_{3} & 3.1 & \text { loss on ignition } & 1.6 \\ \mathrm{Fe}_{2} \mathrm{O}_{3} & 2.8 & \mathrm{~K}_{2} \mathrm{O} & 0.66 & \mathrm{C}_{3} \mathrm{~S} & 60 \\ \mathrm{Al}_{2} \mathrm{O}_{3} & 4.8 & \mathrm{Na}_{2} \mathrm{O} & 0.12 & \mathrm{C}_{2} \mathrm{~S} & 13 \\ \mathrm{CaO} & 64.1 & \mathrm{TiO}_{2} & 0.29 & \mathrm{C}_{3} \mathrm{~A} & 8 \\ \mathrm{MgO} & 1.0 & \mathrm{P}_{2} \mathrm{O}_{5} & 0.15 & \mathrm{C}_{4} \mathrm{AF} & 8.5\end{array}$

examined as a function of time and $\mathrm{pH}$. Two kinetic models of first and second orders were used to describe the kinetics of metal removal. The likely speciation of metal species in a "solution-carbonated cement" system was assessed with the help of PHREEQC modeling, supported by XRD analysis.

\section{Experimental Section}

Sorbent Synthesis. Immediately prior to carbonation, PC (Table 1) was mixed with deionized water at a water/solid ratio of 0.1 and placed in a carbonation chamber (Figure 1) containing $100 \%$ purity $\mathrm{CO}_{2}$. The gas pressure was adjusted to 2 bar $(0.2 \mathrm{MPa})$ to enhance diffusion of $\mathrm{CO}_{2}$ into the powdered substrate. Due to the fact that carbonation could be limited to the reactive surface of a powdered material, PC was repeatedly exposed to moisture and $\mathrm{CO}_{2}$ with intermediate grinding (over $2-3 \mathrm{~min}$ ) and drying at $40{ }^{\circ} \mathrm{C}$. Each carbonation cycle lasted for $1-2 \mathrm{~h}$. Two batches of carbonated cement (hereafter, calcium aluminosilicate material, CASM) were obtained, one after three carbonation cycles (referred to as batch I), and the other after five carbonation cycles (batch II). The final products were oven-dried and stored in polyethylene bags in a desiccator.

Material Characterization. The PC and CASM were examined using the analytical techniques listed below.

X-ray powder diffraction (Siemens D500 X-ray diffractometer and Kristalloflex 810 generator with $\mathrm{Cu} \mathrm{K \alpha}$ radiation) was used to examine the crystalline constituents of the cement before and after carbonation.

TG-DTA was performed on a Stanton Redcroft STA 780 simultaneous thermal analyzer. A sample of $20 \mathrm{mg}$ was packed into a ceramic crucible, and heated in air at a flow rate of $10{ }^{\circ} \mathrm{C} \mathrm{min}{ }^{-1}$ from 20 to $1000{ }^{\circ} \mathrm{C}$, using an alumina reference material.

Solid-state NMR spectroscopy was employed to investigate the structure of both crystalline and amorphous phases. ${ }^{29} \mathrm{Si}$ and ${ }^{27} \mathrm{Al}$ spectra were acquired at 59.5 and $78.20 \mathrm{MHz}$, respectively, using a Varian Infinity Plus 300 spectrometer equipped with an Oxford Instruments 7.05 T superconducting solenoid, and Chemagnetics magic-angle spinning (MAS) probes. Samples were spun at 4 and $10 \mathrm{kHz}$ in 6 and $4 \mathrm{~mm}$ zirconia rotors for ${ }^{29} \mathrm{Si}$ and ${ }^{27} \mathrm{Al}$ analysis, respectively. The ${ }^{29} \mathrm{Si}$ spectra were excited with a $45^{\circ}$ pulse, with a pulse delay of $5 \mathrm{~s}$, and acquired directly. The ${ }^{1} \mathrm{H}-{ }^{29} \mathrm{Si}$ cross polarization (CP) spectra were acquired using a Hartman-Hahn field strength of $40 \mathrm{kHz}$ with a contact time of $3 \mathrm{~ms} .{ }^{27} \mathrm{Al}$ MAS NMR spectra were acquired with a pulse delay of $1 \mathrm{~s}$, and a short excitation pulse to ensure uniform excitation.

Scanning electron microscopy and electron probe microanalysis were carried out on a JEOL JSM-53C scanning electron microscope equipped with a LINK 860 energydispersive X-ray (EDX) analysis system, and Oxford Instruments ISIS software. Specimen preparation procedures involved vacuum impregnation of powdered samples with epoxy resin and polishing in oil. An accelerating voltage of $20 \mathrm{kV}$ was employed for analysis.

Nitrogen gas adsorption was conducted on a six-port Quantachrome Autosorb automated gas sorption system, AS6. Prior to nitrogen adsorption, samples were heated under vacuum pressure lower than $1 \mathrm{~Pa}$ at $100^{\circ} \mathrm{C}$ for $20 \mathrm{~h}$. Specific surface areas were calculated using the Brunauer, Emmett, and Teller (BET) equation, and pore size distribution was evaluated using the Barret, Joyner, and Halenda algorithm.

Batch Kinetic Study. The kinetics of metal removal by CASM (batch II) was investigated in a batch experiment. Batches were run in triplicate with single-metal solutions of cobalt(II), lead(II), copper(II), chromium(III), molybdenum(VI), cadmium(II), nickel(II), zinc(II), and nonradioactive strontium(II) and cesium(I). Metal solutions (1000 $\mathrm{mg} \mathrm{L}^{-1}$ ) were prepared from analytical grade metal nitrate salts and deionized water. The dose of CASM was fixed at $5 \mathrm{~g} \mathrm{~L}^{-1}$. Blank experiments were performed to check the extent of metal sorption/precipitation on the surface of the polyprothe samples were centrifuged at $4000 \mathrm{rpm}$, and a subsample of supernatant liquors was taken for metal analysis by inductively coupled plasma optical emission spectroscopy (ICP-OES; Iris simultaneous spectrometer). Cesium was quantified by means of atomic emission spectroscopy on a Philips PYE UNICAM SP9-AAS. The same procedure was used to study the effect of initial solution $\mathrm{pH}$ on metal removal efficiency.

The quantity of metal removed, $q_{t}\left(\mathrm{mg} \mathrm{g}^{-1}\right.$ of CASM), at time $t$ was deduced from the mass balance between the initial metal concentration and the concentration at time $t$ in solution, divided by the dose of CASM $\left(5 \mathrm{~g} \mathrm{~L}^{-1}\right)$. Pseudofirst-order and pseudo-second-order kinetic models were used to determine the removal rates of metal ions.

The pseudo-first-order equation is widely used to express the rate of solute sorption:

$$
\log \left(q_{\mathrm{e}}-q_{t}\right)=\log q_{\mathrm{e}}-\frac{k_{1}}{2.303} t
$$

where $k_{1}\left(\mathrm{~min}^{-1}\right)$ is the rate constant of sorption, $q_{\mathrm{e}}\left(\mathrm{mg} \mathrm{g}^{-1}\right)$ is the amount of metal removed at equilibrium, and $q_{t}$ (mg $\mathrm{g}^{-1}$ ) is the amount of metal at the surface of a sorbent at any time $t$ (min).

The pseudo-second-order equation may also describe the sorption kinetics:

$$
\frac{t}{q_{t}}=\frac{1}{v_{0}}+\frac{1}{q_{\mathrm{e}}} t
$$

where $k_{2}\left(\mathrm{~g} \mathrm{mg}^{-1} \mathrm{~min}^{-1}\right)$ is the rate constant of sorption and $v_{0}=k_{2} q_{\mathrm{e}}^{2}$ is the initial sorption rate. The values of $v_{0}$ and $q_{\mathrm{e}}$ can be determined experimentally by plotting $t / q_{t}$ versus $t$.

Metal Removal Mechanism. After $120 \mathrm{~h}$ of contact with a metal solution CASM was recovered, freeze-dried, and analyzed by XRD to identify any crystalline phases formed pylene bottles. At time intervals of $6,24,48,72$, and $120 \mathrm{~h}$, 


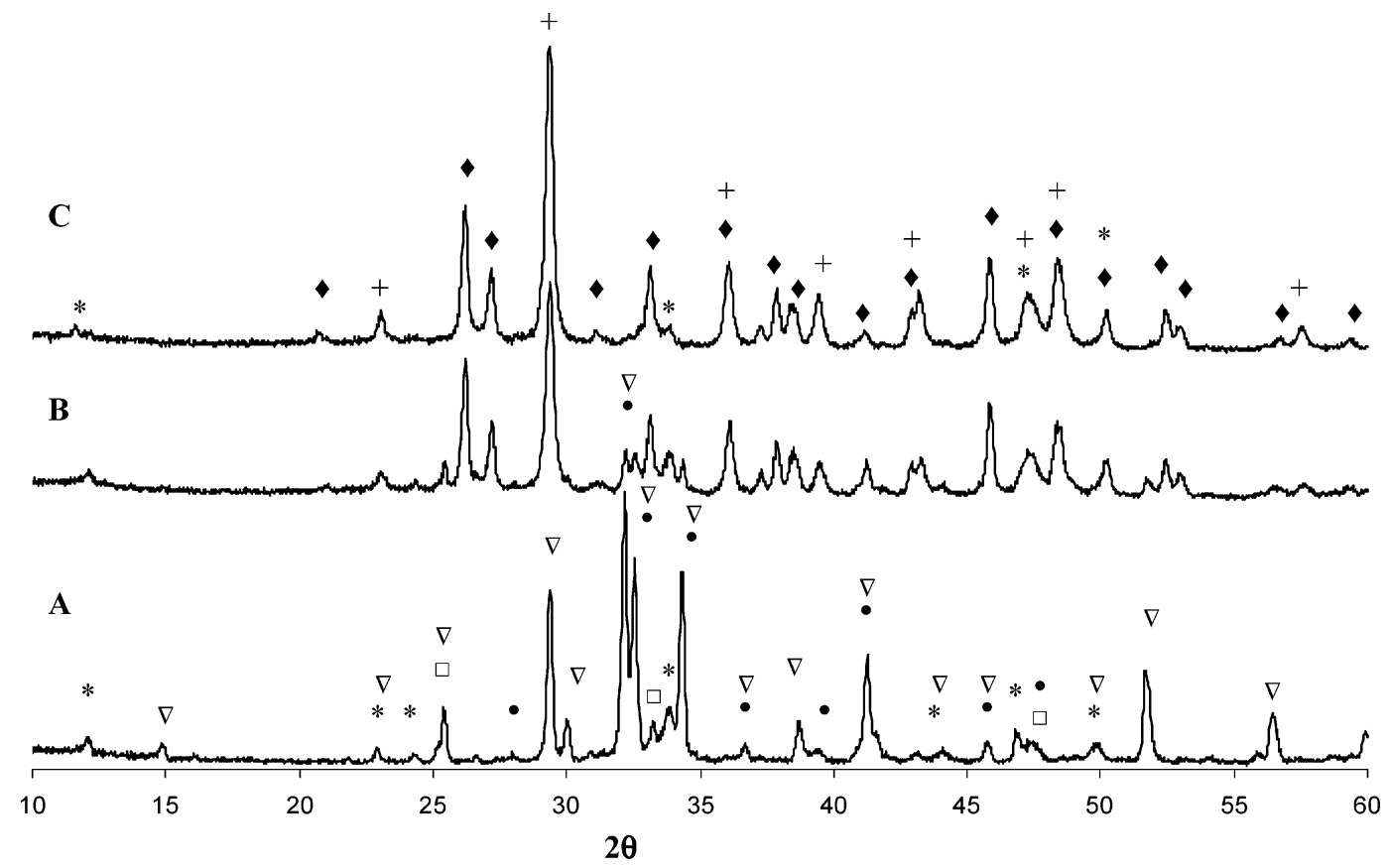

FIGURE 2. XRD patterns of OPC (A), CASM obtained after three carbonation cycles (B), and CASM obtained after five carbonation cycles (C). Mineral phases depicted: $(\diamond)$ aragonite, $(+)$ calcite, $(\bullet) C_{2} S,(\square) C_{3} A,(\nabla) C_{3} S,(*) C_{4} A F$.

as a result of metal precipitation/nucleation. PHREEQC simulation (24) was used to assess metal speciation in batch tests.

Sorbent Stability Tests. The acid neutralization capacity (ANC) test was used to measure the buffering capacity of the carbonated material. The ANC test was carried out in duplicate in loosely closed bottles to allow gaseous exchange with the atmosphere. Different volumes of $4 \mathrm{~N} \mathrm{HNO}_{3}$ acid were added to CASM, while the solid/liquid ratio remained constant ( $5 \mathrm{~g}$ in $30 \mathrm{~mL}$ ). After acid dosing, the bottles were agitated for $48 \mathrm{~h}$, and then the $\mathrm{pH}$ was measured.

A test similar in nature to the ANC test was employed to examine the structural stability of CASM in aqueous media. A $1 \mathrm{~g}$ sample of CASM was placed in $200 \mathrm{~mL}$ of deionized water (solid/solution ratio adapted from the batch sorption study), and the $\mathrm{pH}$ was adjusted separately to $2,4,6$, 8, and 10 , where it was maintained for a period of up to $600 \mathrm{~h}$. The solubility of the major CASM compositional ions, $\mathrm{Ca}, \mathrm{Si}, \mathrm{Al}$, $\mathrm{Mg}, \mathrm{Fe}$, and $\mathrm{K}$, was monitored at the specified $\mathrm{pH}$ values and contact times of $6,24,48,72,120,200$, and $600 \mathrm{~h}$. The experiment was conducted in triplicate, and the samples were analyzed by ICP. After $600 \mathrm{~h}$, liquid and solid phases were separated by centrifugation at $4000 \mathrm{rpm}$. The solid phase was freeze-dried and examined by SEM, TG-DTA, and XRD for any microstructural changes, which could have resulted from the exposure to acidic and alkaline environments.

\section{Results and Discussion}

CASM Characterization. (A) $X$-ray analysis of CASM (Figure 2) showed strong $\mathrm{CaCO}_{3}$ reflections, which are characteristic of calcite and aragonite. This finding is consistent with those of the previous studies, where the formation of these two calcium carbonate polymorphs was observed in carbonated calcium silicates (5). Some researchers have reported that vaterite, the least stable calcium carbonate polymorph, also formed during carbonation $(4,6)$.

Some unreacted $\mathrm{C}_{2} \mathrm{~S}$ and $\mathrm{C}_{3} \mathrm{~S}$ were found in CASM obtained in three carbonation cycles; however, after five cycles, dicalcium and tricalcium silicates were no longer detectable. The persistence of X-ray reflections from $\mathrm{C}_{4} \mathrm{AF}$ indicated that this phase was generally unmodified by carbonation. It is interesting to note that Anthony et al. (21), who studied accelerated carbonation of pure $\mathrm{C}_{4} \mathrm{AF}$, has reported a poor reactivity of this mineral (around 5\%).

The XRD analysis did not identify any crystalline silicate phases resulting from carbonation of calcium silicates.

(B) Nitrogen adsorption studies showed that the BET specific surface area of CASM was 5 times greater $\left(49 \mathrm{~m}^{2} \mathrm{~g}^{-1}\right)$ than that of PC $\left(10 \mathrm{~m}^{2} \mathrm{~g}^{-1}\right)$. The nitrogen isotherm obtained for PC was identified as type III (Brunauer classification (25)), which was characteristic of nonporous materials. The adsorption-desorption isotherm of CASM was of type III with a hysteresis loop, indicating developing porous structure, with calculated pore radii in the region of $30-40 \AA$.

(C) Microstructural examination by backscatted electron imaging (BSE), element mapping, and quantitative EDX analysis was carried out on polished samples of CASM from both batches I and II. Images and element maps were collected from about 10 areas. Approximately 20 EDX analyses were obtained from each of these areas.

BSE images (Figure 3 ) revealed that CASM had a stratified structure consisting of a $\mathrm{Si}$-rich phase, a $\mathrm{CaCO}_{3}$-rich phase, and unreacted $\mathrm{C}_{4} \mathrm{AF}$. Some unreacted $\mathrm{C}_{2} \mathrm{~S}$ and $\mathrm{C}_{3} \mathrm{~S}$ were also observed in CASM, produced by three cycles of carbonation (Figure 3, panel 4). The morphology of the carbonated cement was probably influenced by the grinding process, which could have caused separation of reaction products. Discrete calcium carbonate-rich (medium gray scale) and Si-rich (darker gray scale) regions were observed, and these are shown in Figure 3 , panels $1-3$. Unreacted $\mathrm{C}_{4} \mathrm{AF}$ appeared as bright welldefined interstitial phases in the images.

CASM from batch I was formed of approximately $20 \%$ poorly carbonated cement grains (Figure 3, panel 4). Element maps (Figure 4) of the CASM particle (Figure 3, panel 4) depict insignificant decalcification of the original cement grain. The outer region of the grain is Ca-rich, with characteristic $\mathrm{Ca} / \mathrm{Si}$ atom ratios between 4 and 8 . A partly decalcified region with $\mathrm{Ca} / \mathrm{Si}$ atom ratios between 0.3 and 1 surrounds the unreacted core of the grain. When the degree of carbonation was higher, as in CASM batch II (Figure 3, panels $1-3$ ), the $\mathrm{Ca} / \mathrm{Si}$ ratios were primarily in the ranges of $10-21$ and $0.03-0.3$, respectively. By way of example, the distribution of $\mathrm{Ca} / \mathrm{Si}$ ratios determined by $42 \mathrm{EDX}$ spot analyses of the Si-rich areas of CASM batch II grains is 


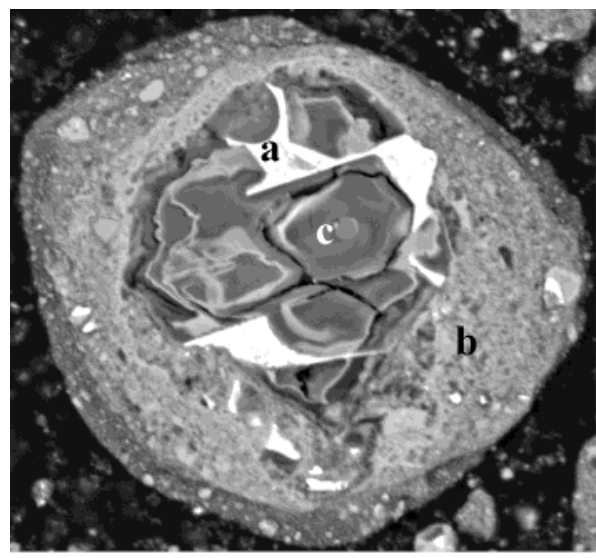

(1)

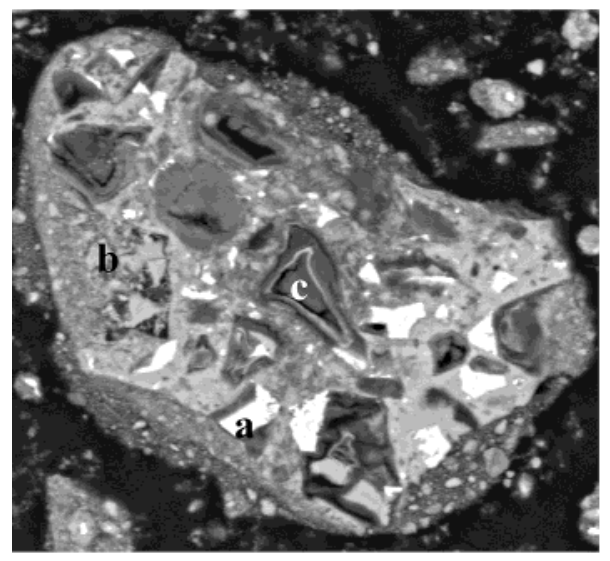

(3)

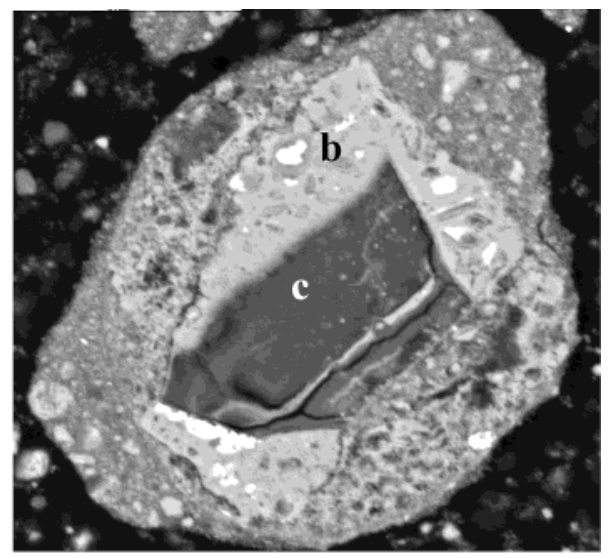

(2)

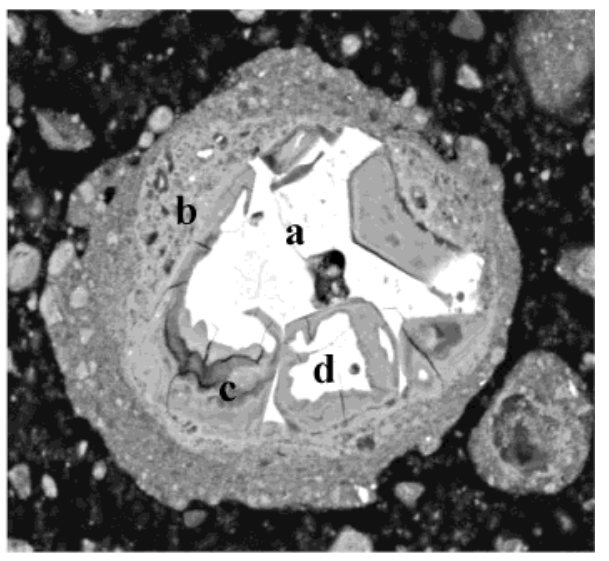

(4)

FIGURE 3. BSE images of CASM polished sections: (a) $\mathrm{C}_{4} A F$; (b) Ca-rich phase; (c) Si-rich phase; (d) $\mathrm{C}_{3} \mathrm{~S}, \mathrm{C}_{2} \mathrm{~S}$.

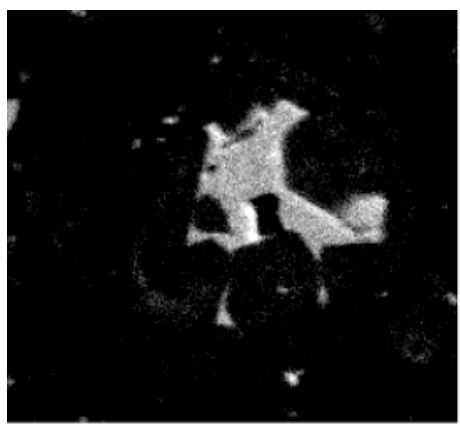

(a)

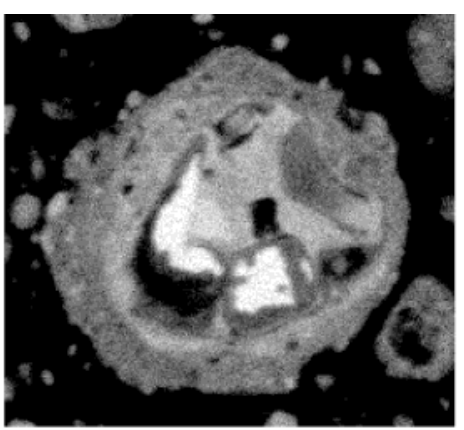

(b)

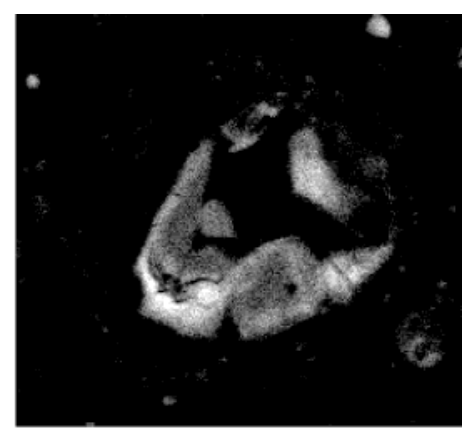

(c)

FIGURE 4. EDX element mapping micrographs of CASM particles (Figure 3, panel 4): (a) Al distribution (identical to Fe); (b) Ca distribution; (c) Si distribution.

presented in Figure 5. Small amounts of $\mathrm{Mg}$, $\mathrm{K}$, and $\mathrm{Al}$ were recorded in both $\mathrm{Ca}$ - and Si-rich phases, with $\mathrm{Al}$ and $\mathrm{Mg}$ predominance in the latter phase.

Goodbrake et al. (5) calculated the stoichiometries of "silica-gel-like" areas in carbonated $\mathrm{C}_{3} \mathrm{~S}$ using quantitative XRD and thermogravimetric analysis. They observed that $\mathrm{Ca} / \mathrm{Si}$ atomic ratios progressively decreased as carbonation time increased to 0.5 and 0.1 when about $50 \%$ and $90 \%$ of the starting material was reacted, respectively. Though these results are related to the carbonation products of singlemineral phases, the $\mathrm{Ca} / \mathrm{Si}$ ratios recorded are similar to those found here for CASM.

The composition and morphology of $\mathrm{C}_{4} \mathrm{AF}$ was not affected by accelerated carbonation, as the element ratios remained unchanged, indicating that the extent of any reaction, which may have taken place, was negligible. This is in agreement with XRD.
(D) NMR. The ${ }^{29}$ Si MAS NMR spectrum of cement clinker (Figure 6) showed a peak at $-71 \mathrm{ppm}$, which resulted from monomeric $\mathrm{Q}^{0}$ silicate species found in $\mathrm{C}_{3} \mathrm{~S}$ and $\mathrm{C}_{2} \mathrm{~S}$. A single broad resonance from -85 to $-120 \mathrm{ppm}$ in the CASM (batch II) spectrum (Figure 6) was assigned to a continuous range of $\mathrm{Q}^{2-4}(0-1 \mathrm{Al})$ silicate units. In accordance with convention, $\mathrm{SiO}_{4}$ units are identified in relation to their mutual connectivity as $\mathrm{Q}^{n}(m \mathrm{Al})$, where $\mathrm{Q}$ is a silicate tetrahedron connected via oxygen bridges to $m \mathrm{Al}$ and $n-m$ other $\mathrm{Si}$ atoms, with $n=0-4$ and $m=0-n$ (26). Replacement of one or more $\mathrm{Si}$ atoms by $\mathrm{Al}$ atoms in the outer coordination sphere of a $\mathrm{Q}^{n}$ unit results in lower field shifts (i.e., less negative $\delta$ values), arising from deshielding. A signal maximum at 103 ppm for the chemical shift distribution of the CASM ${ }^{29} \mathrm{Si}$ spectrum showed that the silicate groups are primarily organized in three-dimensional networks of $\mathrm{Q}^{3}$ ( -95 to -103 ppm), $\mathrm{Q}^{4}$ (-103 to $\left.-120 \mathrm{ppm}\right)$, and $\mathrm{Q}^{4}$ (1 Al) ( -97 to -108 


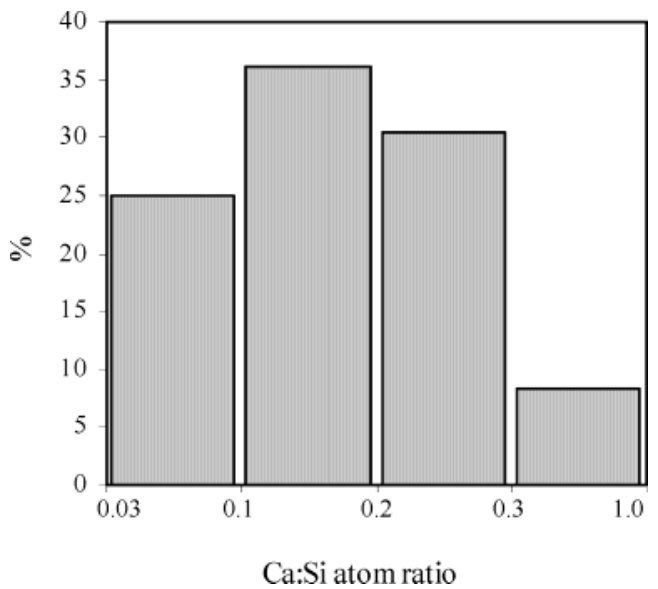

FIGURE 5. Distributions of $\mathrm{Ca} / \mathrm{Si}$ atom ratios in Si-rich areas of CASM (batch II).

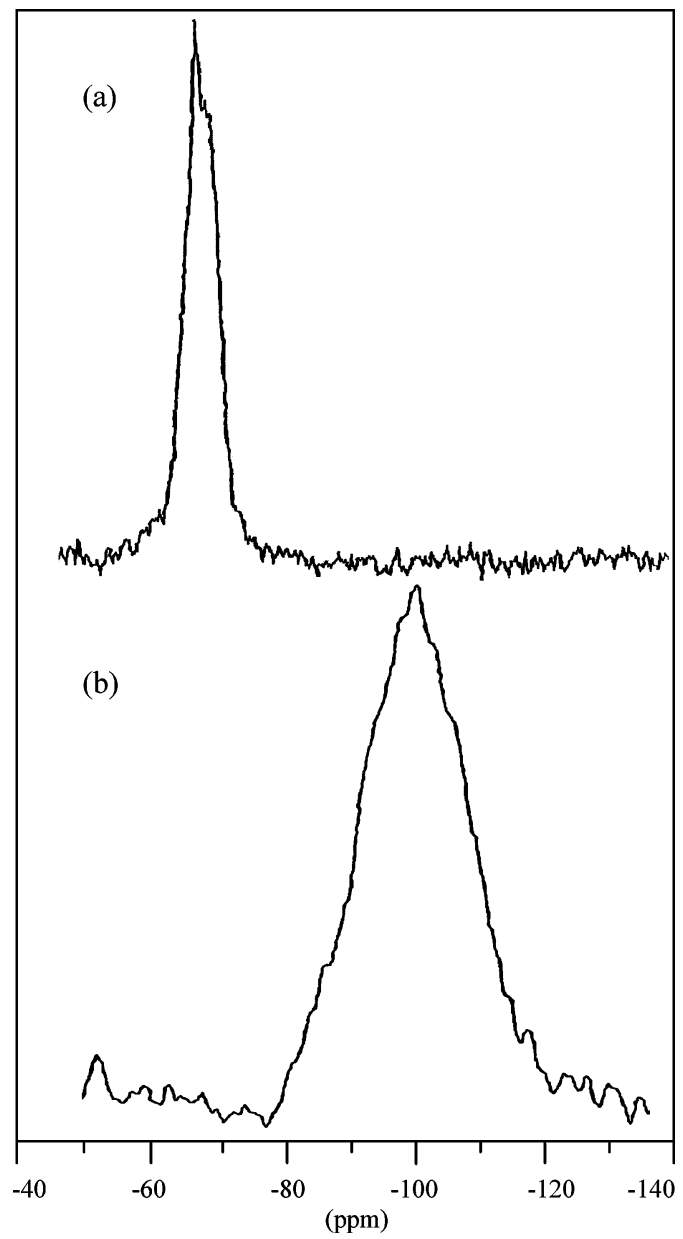

FIGURE 6. ${ }^{29} \mathrm{Si}$ M AS NM R spectra of PC (a) and CASM (b) obtained at $59.5 \mathrm{M} \mathrm{Hz}$ and a spinning speed of $4 \mathrm{kHz}$. ppm) silicate tetrahedra. Small fractions of silicon were present as $\mathrm{Q}^{3}$ ( $\left.1 \mathrm{Al}\right)(-89$ to $-97 \mathrm{ppm})$ and $\mathrm{Q}^{2}(-85$ to -95 ppm) environments. The incorporation of aluminum into the Si-rich phase was consistent with the results of quantitative SEM-EDX analysis (Al/Si ratios of $0.04-0.1$ ).

The ${ }^{1} \mathrm{H}-{ }^{29} \mathrm{Si}$ cross polarization spectrum of CASM showed a broad nondistinct peak similar to that of the ${ }^{29} \mathrm{Si}$ MAS spectrum. This indicates that the Si phase contains $\mathrm{OH}$ groups or water molecules in the immediate vicinity of the silicon atoms. NMR as a most useful technique to quantify the structure of
Recent research on ${ }^{27} \mathrm{Al}$ of Portland cements has employed

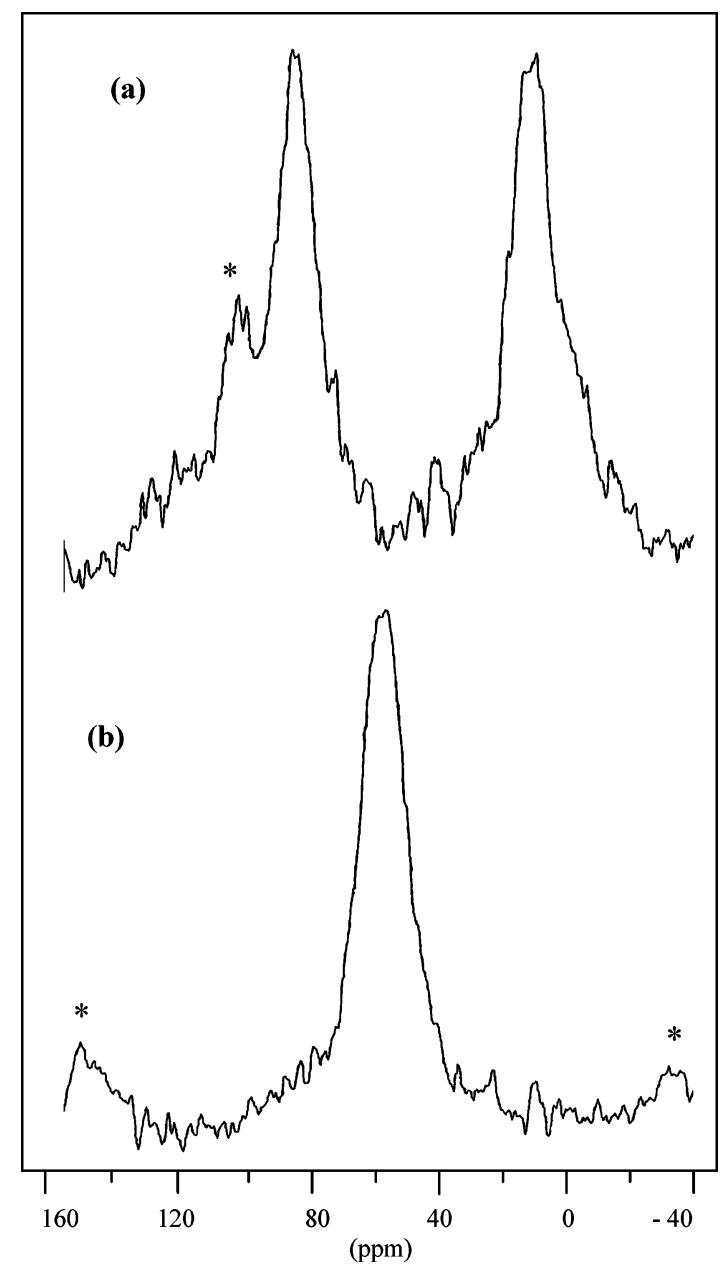

FIGURE 7. ${ }^{27} \mathrm{Al} M$ MS NM R spectra of the central transitions for PC (a) and CASM (b) obtained at $78.2 \mathrm{M} \mathrm{Hz}$ and a spinning speed of 10 kHz. Positions of spinning sidebands are indicated by asterisks.

$\mathrm{C}_{3} \mathrm{~A}$, and provide information on the $\mathrm{Al}$ guest ions incorporated into $\mathrm{C}_{2} \mathrm{~S}$ and $\mathrm{C}_{3} \mathrm{~S}(29-31)$. The aluminum present in the paramagnetic ferrite, $\mathrm{C}_{4} \mathrm{AF}$, contributes little or not at all to the ${ }^{27} \mathrm{Al}$ spectra (27). The ${ }^{27} \mathrm{Al}$ spectrum of PC obtained in this study (Figure 7) had peaks centered at 81 and $8 \mathrm{ppm}$ (the $100 \mathrm{ppm}$ peak was a spinning sideband). The $81 \mathrm{ppm}$ peak was assigned to $\mathrm{AlO}_{4}$ species incorporated into calcium silicates, while the peak at 8 ppm was assigned to $\mathrm{AlO}_{6}$ species, perhaps due to a little hydration of the cement. It should be noted that the $\mathrm{Al}$ present in ferrite phases was largely not observed in these spectra. Upon carbonation, these center bands were replaced by a well-defined signal at $53 \mathrm{ppm}$ (Figure 7). This was not in the region expected for aluminum substituted into $\mathrm{C}-\mathrm{S}-\mathrm{H}$ (approximately $70 \mathrm{ppm}(26,27)$ ), but is instead in the region expected (28) for aluminum substituted into a cross-linked silica network, such as a silica gel or zeolite. This is a clear indication that tricalcium aluminate was altered during the carbonation reaction. The distinct tetrahedral aluminum in CASM was, in all probability, located in the polymerized silicate structures as guest ions. Octahedral $\mathrm{AlO}_{6}$ species, such as those found in alumina gel and ettringite (expected in the region $0-15 \mathrm{ppm}$ (31)), which represent the potential products of hydrated or carbonated hydrated cement, were not detected. This means that the carbonation of anhydrous cement in the presence of water $(10 \%)$ did not involve the typical hydration reactions of cement minerals, including $\mathrm{C}_{3} \mathrm{~A}$.

(E) TG-DTA. The results of thermogravimetric analysis of CASM are shown in Figure 8. The endothermic peak in the low-temperature region $\left(<300{ }^{\circ} \mathrm{C}\right)$ represents dehydration 


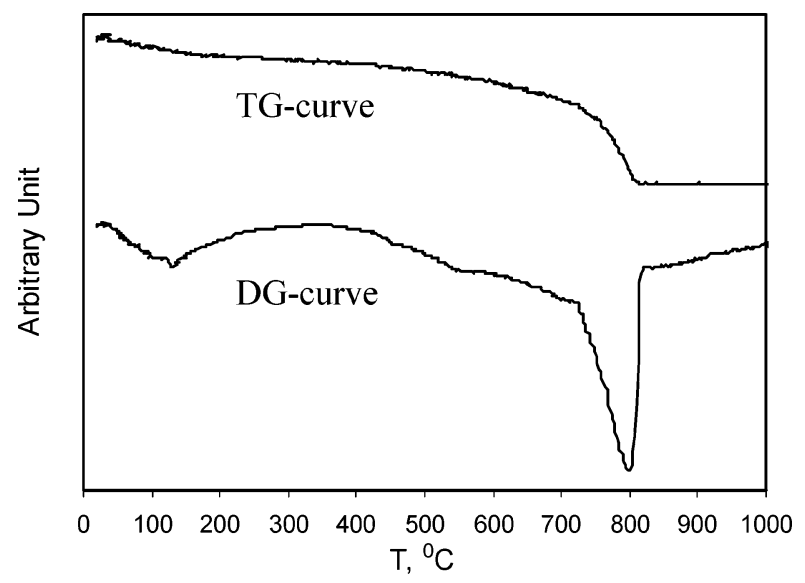

FIGURE 8. TG and DT curves of CASM (batch II), obtained in air flow, at a heating rate of $10^{\circ} \mathrm{C}$.

of free water and water molecules from hydrated cations and external mineral surfaces and the dehydroxylation of a range of hydroxyl groups.

It is known that (orthorhombic) aragonite transforms reconstructively to calcite (trigonal) at $\sim 450{ }^{\circ} \mathrm{C}$ (32). The illdefined exotherm at around this temperature was ascribed to this phenomenon. The high-temperature endotherm at $800^{\circ} \mathrm{C}$ denoted decomposition of calcite. To explain the origin of the small endotherm occurring at $550{ }^{\circ} \mathrm{C}$, we should refer to the work in which TG-DTA and gas-phase mass spectroscopy were used to examine the carbonation products of anhydrous $\mathrm{C}_{3} \mathrm{~S}$ and $\mathrm{C}_{2} \mathrm{~S}(9)$. The low-temperature decarbonation at $\sim 550{ }^{\circ} \mathrm{C}$ was stated to be a result of decomposition of amorphous calcium silicate hydrocarbonate, as after thermal treatment at this temperature $\mathrm{CaO}$ (the final product of $\mathrm{CaCO}_{3}$ and $\mathrm{Ca}(\mathrm{OH})_{2}$ thermal decomposition) was not detected by XRD (3). In our work, an analogous phase could have been formed in addition to the main carbonation products. Calcium ions present in the polymerized silicate framework, especially those at the edges of open structures, are likely to be subjected to carbonation and hydration.

Using thermogravimetric data, we determined $\mathrm{CO}_{2}$ uptake during three and five cycles of carbonation as $32 \%$ and $38 \%$, respectively. The maximum theoretical $\mathrm{CO}_{2}$ capacity of cement clinker is $49 \%$, calculated from eq 3 as proposed by Steinour (33), indicating that up to $80 \%$ of the starting material reacted with $\mathrm{CO}_{2}$. In eq $3,[\mathrm{CaO}],\left[\mathrm{Na}_{2} \mathrm{O}\right]$, and $\left[\mathrm{K}_{2} \mathrm{O}\right]$ are the mass percentages of the respective oxides in cement:

$$
\begin{aligned}
& {\left[\mathrm{CO}_{2}\right](\%)=} \\
& \quad 0.785\left([\mathrm{CaO}]-0.7\left[\mathrm{SO}_{3}\right]\right)+1.09\left[\mathrm{Na}_{2} \mathrm{O}\right]+0.93\left[\mathrm{~K}_{2} \mathrm{O}\right]
\end{aligned}
$$

(F) Concluding Remarks. A number of workers have investigated the carbonation products of anhydrous calcium silicates $(4,5,7)$ using XRD and TG-DTA techniques. They suggested that the carbonation process initially forms $\mathrm{CaCO}_{3}$ and $\mathrm{C}-\mathrm{S}-\mathrm{H}$ according to

$$
\mathrm{C}_{n} \mathrm{~S}+(n-x) \mathrm{CO}_{3}{ }^{2-}+y \mathrm{H}^{+} \rightarrow \mathrm{C}_{x} \mathrm{SH}_{y}+(n-x) \mathrm{CaCO}_{3}
$$

The $\mathrm{C}-\mathrm{S}-\mathrm{H}$ was assumed to be similar to that found in conventionally hydrated cement, but was believed to carbonate rapidly so that the final reaction products were calcium carbonate and silica gel, with the overall reaction being

$$
\mathrm{C}_{n} \mathrm{~S}+n \mathrm{CO}_{3}{ }^{2-}+z \mathrm{H}^{+} \rightarrow \mathrm{SH}_{z}+n \mathrm{CaCO}_{3}
$$

Other authors have questioned the formation of silica gel

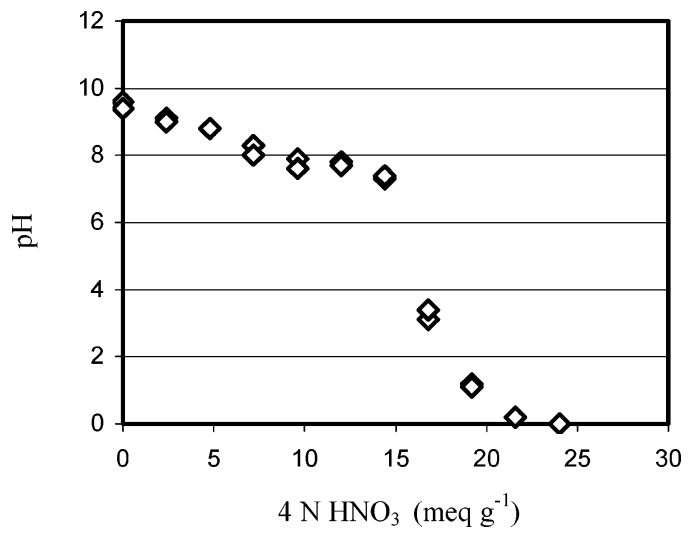

FIGURE 9. Acid neutralization capacity titration curve, obtained for CASM (batch II).

and suggested that amorphous calcium silicate hydrocarbonate constitutes the silica-rich phase (6).

In our work, solid-state NMR, employed for the first time in the structural characterization of carbonated products of anhydrous cement minerals, showed the predominance of 3- and 4-coordinated Si units $\left(Q^{3}\right.$ and $\left.Q^{4}\right)$, a small percentage of $\mathrm{Q}^{2} \mathrm{Si}$ units, and a complete absence of $\mathrm{Q}^{1}$ Si units. This is indicative of a progressive decalcification of $\mathrm{C}_{2} \mathrm{~S}$ and $\mathrm{C}_{3} \mathrm{~S}$ with a consequent polymerization of single silicate units into Ca-modified amorphous silica. This structural calcium could have been carbonated/hydrated at the edges of the silica framework, forming the calcium silicate hydrocarbonate previously cited. ${ }^{29} \mathrm{Si}$ NMR spectra did not show any signs of conventional $\mathrm{C}-\mathrm{S}-\mathrm{H}$, the cement hydration product.

The hypothesis involving $\mathrm{C}-\mathrm{S}-\mathrm{H}$ formation during the initial stages of carbonation is equally questionable. Taking into consideration a relatively small proportion of $\mathrm{H}_{2} \mathrm{O}$ in the mixes subjected to carbonation $(4-7)$ and rapid rates of carbonation in comparison to those of hydration (34) (by a factor of $>10$ ), the development of the conventional hydrated cement phases is likely to be negligible.

${ }^{27} \mathrm{Al}$ NMR data obtained in our work demonstrate that $\mathrm{C}_{3} \mathrm{~A}$ was involved in the accelerated carbonation reaction, with $\mathrm{Al}$ ions being relocated in the structure of the polymerized silicates.

Chemical and Structural Stability. Sorbents are normally evaluated on the basis of certain criteria, including the stability of material in the service environment. As the majority of metal-bearing effluents are acidic, it is important that sorbents are resistant to dissolution. To address this aspect, we monitored the stability of CASM in aqueous media as a function of $\mathrm{pH}$ and time, and assessed the acid buffering capacity of the material.

The results of acid neutralization testing are shown in Figure 9. It is evident that the alkalinity of carbonated cement decreased slightly in response to the initial acid addition until a $\mathrm{pH}$ of around 8 was reached, where a plateau was established. At an acid addition of approximately 16 mequiv $\mathrm{g}^{-1}$, the $\mathrm{pH}$ of the system dropped sharply to below 4 and then decreased progressively. Calcium carbonate is known to buffer aqueous systems at around pH 8 (35), and thus, the acid buffering by CASM was believed to be $\mathrm{CaCO}_{3}$-based. The results of ANC testing show that CASM, or other similar carbonated minerals, can be effective neutralizing agents for acidic metal-bearing waste streams.

The results from the stability testing of CASM at high w/s ratios indicated that dissolution of the main structural elements, $\mathrm{Ca}, \mathrm{Si}, \mathrm{Al}, \mathrm{K}, \mathrm{Mg}$, and $\mathrm{Fe}$, was only pronounced at $\mathrm{pH} \leq 4$, which was in agreement with the results of the ANC test. When the acid buffering capacity was fully exhausted and $\mathrm{pH}$ dropped below 4 , the material underwent significant dissolution: the amounts of $\mathrm{Ca}, \mathrm{Al}, \mathrm{Si}$, and $\mathrm{Fe}$ leached from 
$1 \mathrm{~g}$ of CASM reached $8.1,0.6,0.5$, and $0.18 \mu \mathrm{M}$, respectively, after $600 \mathrm{~h}$ at $\mathrm{pH} 2$ (the worst case scenario). Due to its amphoteric nature, Si was equally prone to dissolution under alkaline conditions ( $\mathrm{pH}$ 12). Time had a noticeable effect on the release of $\mathrm{Al}$ and $\mathrm{Fe}$ at $\mathrm{pH} 2$, and $\mathrm{Si}$ throughout the entire $\mathrm{pH}$ range studied. Polymerized silicates appeared to be structurally stable, and released silicon only after prolonged acid exposure. It can be concluded that CASM dissolution is minimal at $\mathrm{pH}>4$. However, under the most aggressive acidic conditions, when a large quantity of acid was added to overcome the high acid buffering capacity of CASM, and when the $\mathrm{pH}$ was brought down to 2 , the integrity of CASM was adversely affected.

Solid-phase analysis by SEM, XRD, and DTA confirmed that the harsh acidic conditions were detrimental to the integrity of CASM. Calcium carbonate was particularly vulnerable to dissolution, whereas $\mathrm{C}_{4} \mathrm{AF}$ appeared to hydrate into an amorphous phase. The $\mathrm{Ca} / \mathrm{Al}$-modified amorphous silica phase released most of the $\mathrm{Ca}$ and $\mathrm{Al}$, and further polymerized into a silica gel.

Sorption Kinetics of Metal Ions. The removal of metals by CASM (batch II) was examined as a function of time and $\mathrm{pH}$ in a batch sorption study, as shown in Figures 10 and 11. The plots represent the amount of metals removed, $q_{t}$, versus time, and changes in the $\mathrm{pH}$ level of the solution during the contact time.

The effect of $\mathrm{pH}$ on metal removal was minimal. As can be seen from the example of Co, Ni, Cs, and Sr (Figure 10), two solutions of each metal were used in a batch study, one having natural $\mathrm{pH}$ (no adjustment) and the other one with adjusted $\mathrm{pH}$ ( 3 or 4 ). After $6 \mathrm{~h}$ of contact with the sorbent, the $\mathrm{pH}$ values of both solutions were buffered to about similar levels.

Equilibrium was achieved relatively fast for lead, cadmium, cobalt, cesium, and strontium. For copper and chromium, it was delayed by slow removal rates, whereas for molybdenum, nickel, and zinc equilibrium was not reached even after $120 \mathrm{~h}$. The reason for the extended equilibrium time could be slow diffusion/reaction-controlled metal fixation mechanisms. For the equilibrated systems we used pseudofirst-order and pseudo-second-order kinetic models to evaluate metal sorption rates.

The kinetics of $\mathrm{Pb}, \mathrm{Cd}, \mathrm{Cs}$, Co, and $\mathrm{Sr}$ removal followed the second-order rate expression. The fits obtained with this model are presented as linear plots of $t / q_{t}$ against time $t$ (Figure 12). As metal removal was not significantly influenced by the $\mathrm{pH}$ of the initial solutions, only the data for metal solutions with the original $\mathrm{pH}$ are shown. The correlation coefficients were greater than 0.989 for contact times of $120 \mathrm{~h}$ (Table 2). The initial sorption rates $v_{0}$ and equilibrium metal uptakes $q_{\mathrm{e}}$ were determined from the plots and are summarized in Table 2. The sorption reaction for copper did not fit the second-order model, but could be approximated by the firstorder kinetics, though with a relatively low correlation coefficient of 0.933 .

Metal Removal Mechanisms. The sorption phenomenon is commonly defined as a broad range of processes responsible for sorbate removal by a sorbent. Various materials have been tested for the removal of metals from aqueous solutions, and it has been shown that sorption mechanisms are often a complex combination of chemical/physical adsorption and surface precipitation. Distinguishing these mechanisms is a difficult and sometimes impossible task, especially for heterogeneous sorbents.

Geochemical studies, carried out on the interaction of heavy metals with calcium carbonate, have shown that adsorption, diadochy (replacement of one element by another within the structure of a crystal), and surface precipitation are the main mechanisms of metal fixation $(36,37)$. Divalent metal ions in solution tend to both displace calcium in the
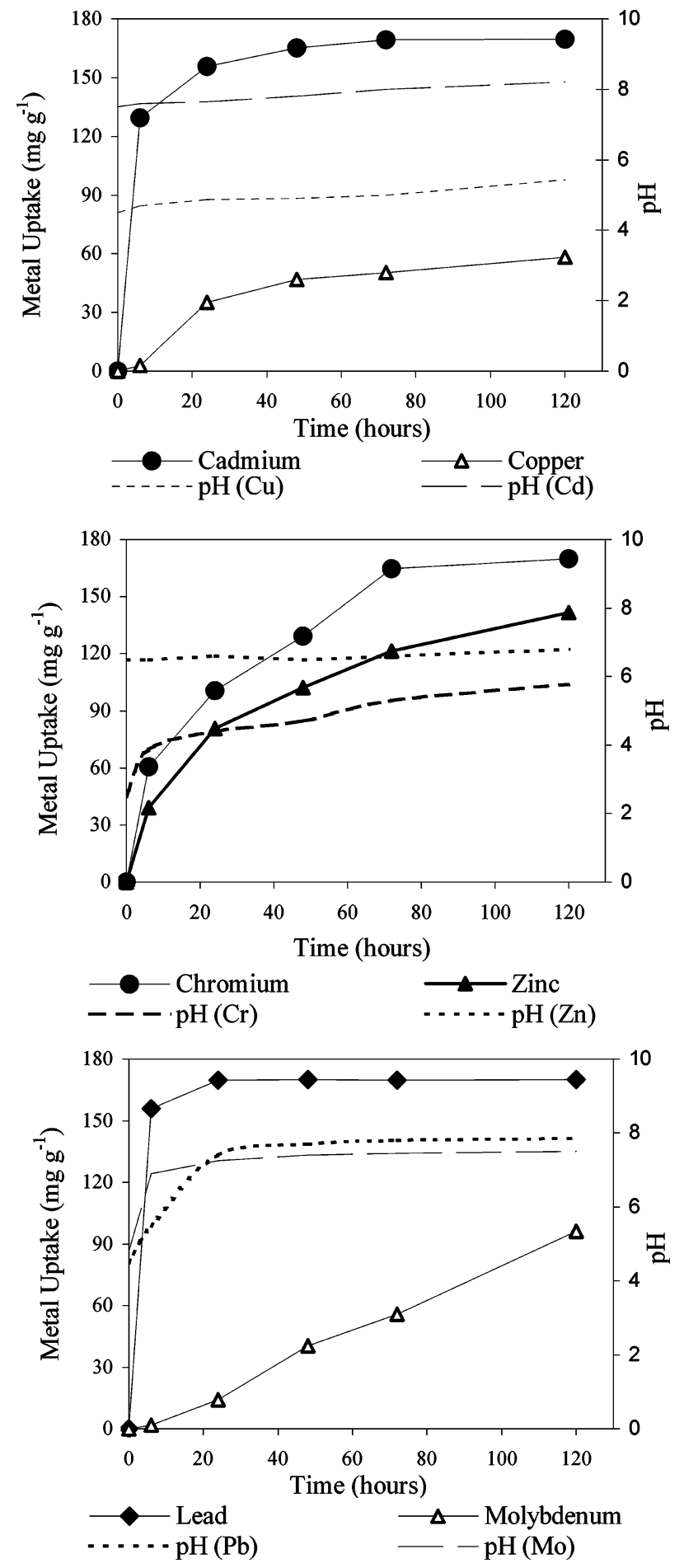

FIGURE 10. Kinetics of $\mathrm{Pb}, \mathrm{Cr}, \mathrm{Mo}, \mathrm{Cd}, \mathrm{Cu}$, and $\mathrm{Zn}$ removal from solutions with the original $\mathrm{pH}$ (no adjustment).

calcite lattice and adsorb and nucleate onto the mineral surface. The latter is relevant to metals with various valences. At high metal concentrations, nucleation and growth of the corresponding metal carbonate, hydroxide, or hydrocarbonate amorphous and crystalline phases are common at calcite surfaces, forming surface precipitates.

In silica systems, surface complexation is postulated as the principle mechanism of metal removal, where metal ions are bound in either "inner sphere" or "outer sphere" complexes $(38,39)$. Nucleation of multilayered metal silicates is also possible.

Having determined CASM as a composition of mainly calcium carbonate and $\mathrm{Ca} / \mathrm{Al}$-modified silica, it would be 

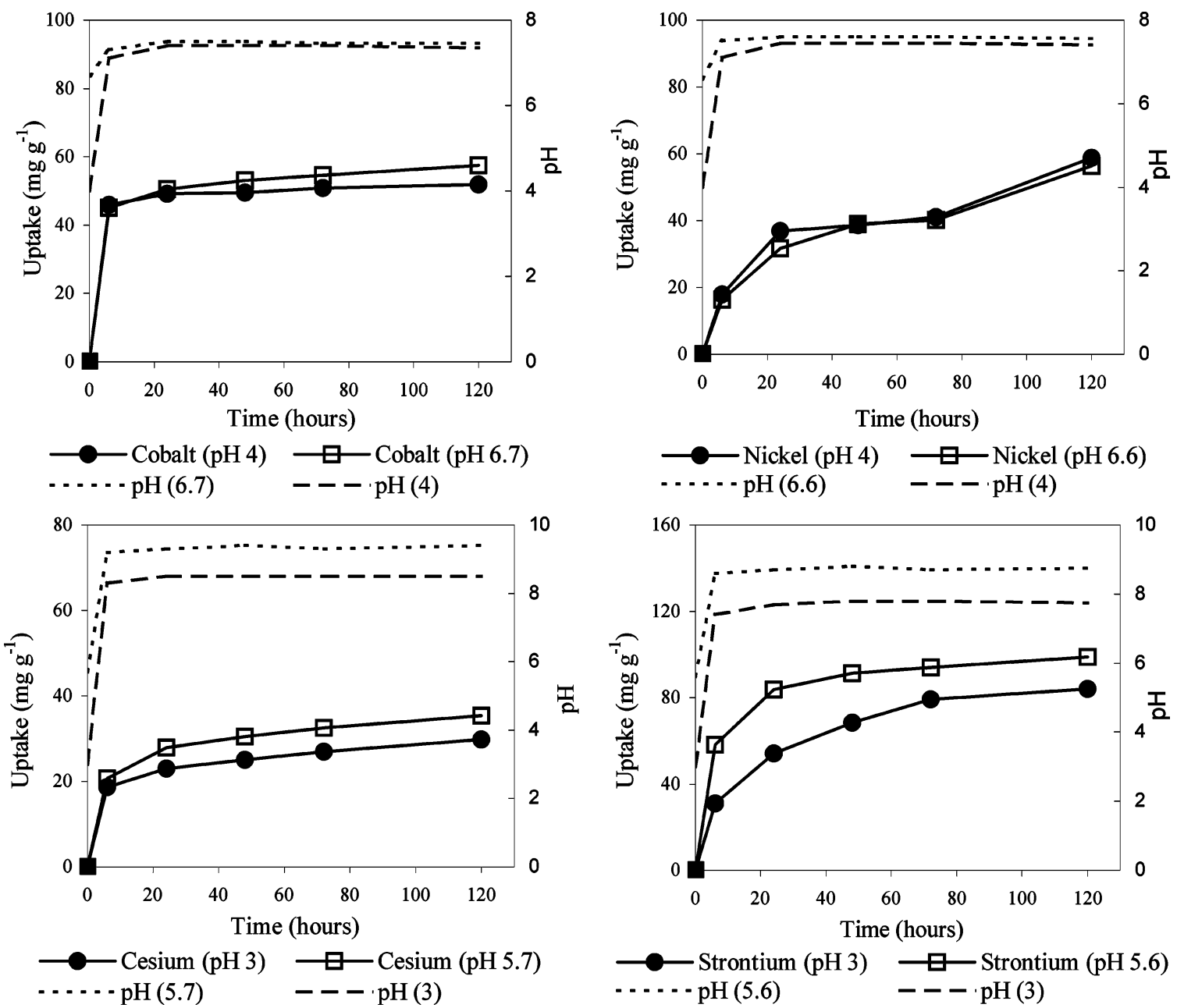

FIGURE 11. Kinetics of $\mathrm{Ni}, \mathrm{Co}, \mathrm{Cs}$, and $\mathrm{Sr}$ removal from solutions with different $\mathrm{pH}$ values.

\section{TABLE 2. Kinetic Parameters for Metal Sorption by CASM}

\begin{tabular}{|c|c|c|c|c|c|}
\hline $\begin{array}{c}\text { metal } \\
\text { ion }\end{array}$ & $\begin{array}{c}k_{2} \\
\left(g^{-1} \min ^{-1}\right)\end{array}$ & $\begin{array}{c}V_{0} \\
\left(m g g^{-1} \min ^{-1}\right)\end{array}$ & $R^{2}$ & $\begin{array}{c}q \mathrm{e} \\
\left(\mathrm{mg} \mathrm{g}^{-1}\right)\end{array}$ & $\begin{array}{c}k_{1} \\
\left(\mathrm{~min}^{-1}\right)\end{array}$ \\
\hline $\begin{array}{l}\text { cesium } \\
\text { cadmium } \\
\text { chromium } \\
\text { cobalt } \\
\text { lead } \\
\text { strontium }\end{array}$ & $\begin{array}{c}5.92 \\
4.37 \\
0.45 \\
2.29 \\
32.9 \\
2.97\end{array}$ & $\begin{array}{c}\text { Second-Order } \\
0.08 \\
1.29 \\
0.18 \\
0.11 \\
9.46 \\
0.32\end{array}$ & $\begin{array}{l}0.996 \\
0.999 \\
0.987 \\
0.992 \\
1 \\
0.999\end{array}$ & $\begin{array}{r}37 \\
172 \\
196 \\
69 \\
169 \\
103\end{array}$ & \\
\hline \multicolumn{6}{|c|}{ First-Order Kinetics } \\
\hline
\end{tabular}

expected that metal sorption mechanisms involve adsorption, complexation, diadochy, ion exchange, and surface precipitation. It should be emphasized, however, that highly concentrated metal solutions were used in this preliminary study, and nucleation/precipitation of various metal phases could be thermodynamically favorable in the studied systems.

Assuming "quasi" thermodynamic equilibrium, we have used the geochemical PHREEQC model to evaluate the speciation of metals in the "solution/CASM" system. Batchreaction calculations were performed on a simplified model system of solid/solution assemblage consisting of calcite, amorphous silica, and metal nitrate solution. Sorbent/metal ratios were equivalent to those used in the experimental batch study, and the calcite/silica ratio has been approximated from the CASM composition as $1 / 0.15$. Under the assumptions and system simplification made, simulation results
(Table 3) were solely used for qualitative interpretation to identify likely metal-phase precipitation. The simulation results were verified by XRD analysis, which confirmed the presence of cerrusite, strontianite, malachite, otavite, and zinc carbonate hydrate. Diffractograms of CASM with cobalt and nickel did not account for any crystalline metal phases, and both nickel and cobalt as well as zinc presumably formed the amorphous silicates. The distribution of metal carbonates and silicates (structural incorporation into the CASM matrix or surface (bulk) precipitation) should be further investigated by SEM.

Cesium is known to be adsorbed by silica-based minerals $(40,41)$ via complexation and ion exchange. In the CASM system the cesium removal mechanism is most likely to be adsorption by $\mathrm{Ca} / \mathrm{Al}$-modified silica. Unlike in the case of cesium, it is difficult to evaluate the contribution of physical/ 

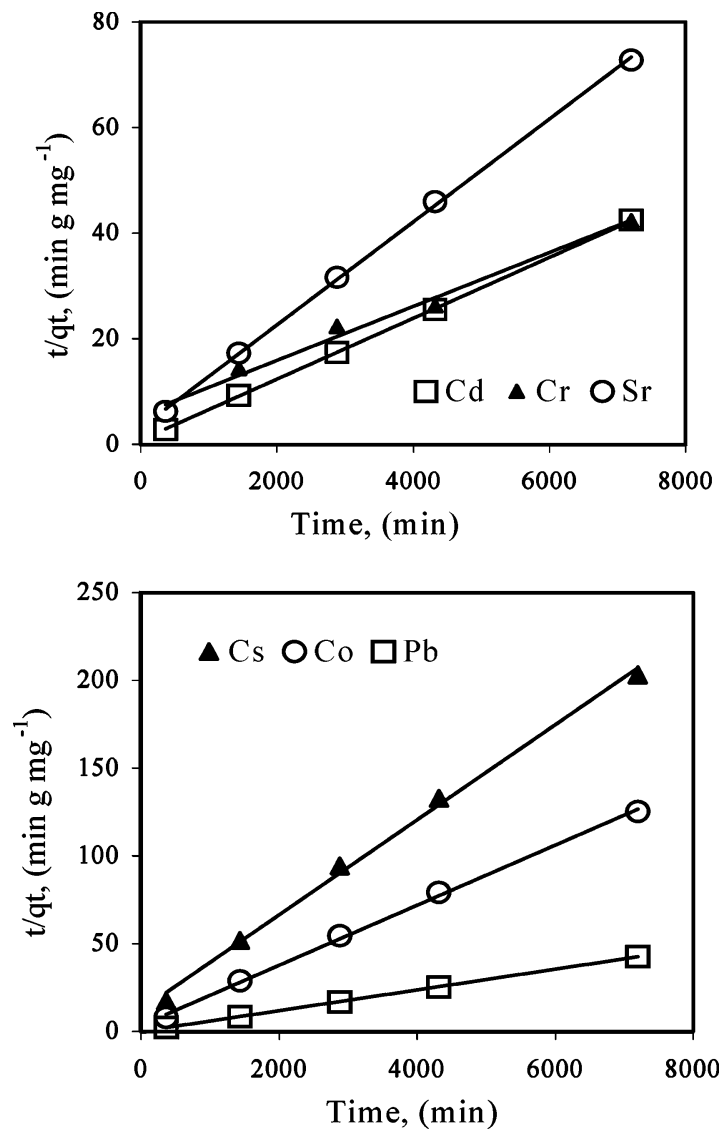

FIGURE 12. Pseudo-second-order kinetics of $\mathrm{Cr}, \mathrm{Sr}, \mathrm{Pb}, \mathrm{Cd}, \mathrm{Co}$, and Cs removal.

\section{TABLE 3. PHREOC Batch-Reaction Calculations}

$\begin{array}{cclc}\begin{array}{c}\text { metal } \\ \text { ion }\end{array} & \begin{array}{c}\text { initial metal concn } \\ \text { in solution } \\ \text { (mmol L-1) }\end{array} & \begin{array}{c}\text { phase formation } \\ \text { at thermodynamic } \\ \text { equilibrium }\end{array} & \begin{array}{c}\text { phase } \\ \text { concn } \\ \text { (mmol L-1) }\end{array} \\ \mathrm{Cr} & 19.32 & \mathrm{Cr}_{2} \mathrm{O}_{3} & 9.66 \\ \mathrm{Ni} & 17.09 & \mathrm{Ni}_{2} \mathrm{SiO}_{4} & 7.17 \\ \mathrm{Zn} & 15.34 & \mathrm{ZnCO}_{3}: \mathrm{H} 2 \mathrm{O} & 6.45 \\ & & \mathrm{ZnSiO}_{3} & 8.50 \\ \mathrm{~Pb} & 4.83 & \text { cerrusite }\left(\mathrm{PbCO}_{3}\right) & 4.55 \\ & & \mathrm{~Pb}(\mathrm{OH}) 2 & 0.28 \\ \mathrm{Cd} & 8.92 & \text { otavite }\left(\mathrm{CdCO}_{3}\right) & 8.91 \\ \mathrm{Cs} & 7.54 & \text { none } & \\ \mathrm{Cu} & 15.78 & \text { malachite }\left(\mathrm{Cu}_{2}(\mathrm{OH})_{2} \mathrm{CO}_{3}\right) & 7.88 \\ \mathrm{Sr} & 11.44 & \text { strontianite }\left(\mathrm{SrCO}_{3}\right) & 9.92 \\ \mathrm{Co} & 17.02 & \text { Co } & \\ & & & 8.50 \\ \end{array}$

chemical adsorption to the total removal of some other studied metals by CASM. In highly concentrated solutions metal species would adsorb selectively onto CASM surface sites, with further nucleation of relevant silicates and carbonates taking place. Subsequent sorption-desorption isotherm work is needed for gaining insight into metal affinity for CASM at low metal concentrations.

The diffractogram of CASM with chromium was analogous to the CASM pattern but heavily distorted, which indicates the formation of bulk hydrated chromium oxide. Although molybdenum is not included in the PHREEQC database, XRD revealed the formation of scheelite $\left(\mathrm{CaMoO}_{4}\right)$.

Future Prospects. The reactivity of natural and synthetic minerals with moisture and $\mathrm{CO}_{2}$ can be utilized to produce functional materials. In the present work, it has been shown that accelerated carbonation of calcium silicate/aluminatebased materials has potential for the synthesis of sorbents.
The carbonated product of anhydrous cement, which consists mainly of calcium carbonate and $\mathrm{Ca} / \mathrm{Al}$-modified amorphous silica, was found to remove metals from concentrated solutions.

In the literature, it has been widely reported that carbonation products of hydrated cementitious minerals are calcium carbonate, modified silica gel, and alumina gel (10, 42,43 ). This allows us to suggest that both anhydrous and hydrated calcium silicate/aluminate minerals found naturally or as constituents of wastes (i.e., ash, slag, and construction waste) represent suitable raw materials for sorbent production by accelerated carbonation. Therefore, future work involving carbonation of different calcium silicate/aluminatebearing substrates and development of a database of their sorption performance with respect to heavy and radioactive metal immobilization is anticipated. The potential application of this type of sorbent is to be sought in the wastewater treatment sector and as a permeable reactive barrier.

\section{Acknowledgments}

This work was conducted under funding from the Department of Sciences at Greenwich University. We thank Ian Slipper and Dave Wray for technical support and Derek Johnson for scientific advising. We also thank anonymous reviewers for their valuable comments.

\section{Literature Cited}

(1) Kojima, T.; Nagamine, A.; Ueno, N.; Uemiya, S. Energy Convers. Manage. 1997, 38, S461.

(2) Lackner, K. S.; Wendt, C. H.; Butt, D. P.; Joyce, E. L. J.; Sharp, D. H. Energy 1995, 20, 1153.

(3) Wu, J. C.; Sheen, J. D.; Chen, S. Y.; Fan Y. C. Ind. Eng. Chem. Res. 2001, 40, 3902.

(4) Bukowski, J. M.; Berger, R. L. Cem. Concr. Res. 1979, 9, 57.

(5) Goodbrake, C. J.; Young, J. F.; Berger, R. L. J. Am. Ceram. Soc. 1979, 62, 168.

(6) Goto, S.; Suenaga, K.; Kado, T. J. Am. Ceram. Soc. 1995, 78, 2867.

(7) Berger, R. L. and Klemm, W. A. Cem. Concr. Res. 1972, 2, 647.

(8) Soroushian, P., Jer-Wen, H. Accelerated curing of cement-based materials. U.S. Patent 5935317, 1999.

(9) Jones, J. R. H. Cement Treated with High-Pressure $\mathrm{CO}_{2}$. U.S. Patent 5650562, 1997

(10) Henry, B. M.; Kilmartin, B. A.; Groves, G. W. J. Mater. Sci. 1997, 32,6249 .

(11) Johnson, D. C.; MacLeod, C. L.; Carey, P. J., Hills, C. D. Environ. Technol. 2003, 24 (6), 671.

(12) Lange, L. C.; Hills, C. D.; Poole, A. B. Environ. Sci. Technol. 1996 $30,25$.

(13) Venhuis, M. A.; Reardon, E. J. Environ. Sci. Technol. 2001, 35, 4120.

(14) Hartmann, T.; Paviet-Hartmann, P.; Rubin, J. B.; Fitzsimmons, M.; Sickafus, K. E. Waste Manage. 1999, 19, 355.

(15) Walton, J. C.; Bin-Shafique, S.; Smith, R. W.; Gutierrez, N.; Tarquin, A. Environ. Sci. Technol. 1997, 31, 2345.

(16) Meima, J. A., van der Weijden, R. D., Eighmy, T. T., Comans, R. N. J. Appl. Geochem. 2002, 17, 1503.

(17) Coleman, N. J.; Brassington, D. S. Mater. Res. Bull. 2003, 38, 485.

(18) Meadowcroft, T. T.; Ionescu D.; Barr P. V.; Murphy J. N. Mater. Trans., JIM 1996, 37 (3), 532.

(19) Huffman, G. P.; Huggins, F. E.; Shan, N.; Shan, A. Prog. Energy Combust. Sci. 1990, 16, 243.

(20) Maries, A. Presented at the Conference in Cement and Concrete Science, Oxford, U.K., September 1992.

(21) Anthony, E. J.; Jia, L.; Woods, J.; Roque, W.; Burwell, S. Waste Manage. 2000, 20 (1), 1.

(22) Isenburg, J.; Moore, M. In Generalized Acid Neutralization capacity test; Stabilization and Solidification of Hazardous, Radioactive and Mixed Wastes; Gilliam T. M., Wiles C. C., Eds.; ASTM STP 1123; American Society of Testing Materials: Philadelphia, 1992; Vol. 2, pp 361-377.

(23) Johnson D. C.; MacLeod C. L.; Hills C. D. Environ. Technol. 2003, 24 (5), 545

(24) Parkhurst, D. L. and Appelo, C. A. J. User's Guide to PHREEQC (Version 2)-A computer program for speciation, batch-reaction, one-dimensional transport, and inverse geochemical calculations; 
U.S. Geological Survey Water-Resources Investigations Report 99-4259; U.S. Geological Survey: Reston, VA, 1999; p 310.

(25) Brunauer, S.; Deming, L. S.; Deming, W. S.; Teller, E. J. Am. Chem. Soc. 1940, 62, 1723.

(26) Gunter, E.; Dieter, M. High-Resolution Solid-State NMR of Silicates and Zeolites; John Wiley \& Sons: London, 1987.

(27) Skibsted, J.; Jakobsen, H. J.; Hall, C. Adv. Cem. Mater. 1998, 7, 57.

(28) Richardson, I. G.; Brough, A. R.; Brydson, R.; Groves, G. W.; Dobson, C. M. J. Am. Ceram. Soc. 1993, 76, 2285.

(29) Andersen, M. D.; Jakobsen, H. J.; Skibsted, J. Inorg. Chem. 2003, 42, 2280.

(30) Mackenzie, K. J.; Smith, M. E. Multinuclear Solid State NMR of Inorganic Materials; Pergamon: Amsterdam, 2002; pp 273-4.

(31) Skibsted, J.; Henderson, E.; Jakobsen, H. J. Inorg. Chem. 1993, $32,1013$.

(32) Mackenzie, R. C. Differential Thermal Analysis; Academic Press: London and New York, 1970; Vols. 1 and 2.

(33) Steinour, H. H. J. Am. Concr. Inst. 1959, 30, 905.

(34) Taylor, H. F. W. Cement Chemistry; Academic Press: London, 1990.
(35) Morse, J. W.; Mackenzie F. T. Geochemistry of Sedimentary Carbonates; Elsevier: Amsterdam, 1990.

(36) Zachara, J. M.; Cowan, C. E.; Resch, C. T. Geochim. Cosmochim. Acta 1991, 55, 1549.

(37) Curti, E. Appl. Geochem. 1999, 14, 433.

(38) Ochs H.; Bublak D.; Wild U. Appl. Surf. Sci. 1998, 133, 73.

(39) Kosmulski, M. Colloids Surf., A 1996, 117, 201.

(40) Shrivastava O. P.; Shrivastava R. Bull. Mater. Sci. 2000, 23 (6), 515.

(41) Marmier N.; Delisee A.; Fromage F. J. Colloid Interface Sci. 1999, $212(2), 228$.

(42) Zhou Q.; Glasser F.P. Kinetics and mechanism of the carbonation of ettringite. Adv. Cem. Res. 2000, 12, 131.

(43) Groves G. W.; Brough A.; Richardson I. G.; Dobson C. M. J. Am Ceram. Soc. 1991, 74 (11), 2891.

Received for review August 15, 2003. Revised manuscript received August 30, 2004. Accepted August 31, 2004.

ES030113T 